\title{
MERCURY AND LEAD TOXICITY INDUCED ALTERATIONS IN THE LIPID METABOLISM OF HETEROMETROUSFULVIPES: A STUDY THROUGH DIRECT EXPOSURE
}

\section{Raghavendra Rao M. V*1., Yogesh Acharya1., Jitender Kumar Naik S², Sireesha Bala1., Samir Fatteh', Simi Paramban' ${ }^{1}$ and Amin S. Fateh1}

\author{
${ }^{1}$ Avalon University School of Medicine, Willemstad, Curacao, Netherland Antilles \\ 20smania University, Hyderabad, Telangana, India
}

DOI: http://dx.doi.org/10.24327/ijrsr.2017.0805.0317

\section{ARTICLE INFO \\ Article History: \\ Received $18^{\text {th }}$ February, 2017 \\ Received in revised form $10^{\text {th }}$ \\ March, 2017 \\ Accepted $06^{\text {th }}$ April, 2017 \\ Published online $28^{\text {th }}$ May, 2017}

Key Words:

Metals, Heavy, Mercury, Lead, Lipid

metabolism, Animal models

\begin{abstract}
Heavy metal exposure in animals can lead to profound effect on growth, development and biochemical constituents. It is necessary that the heavy metal toxicity be well documented and adequate precaution should be taken in mother and fetus to decrease its detrimental effects. An experimental study was performed with viviparous animal Heterometrousfulvipes to access the cumulative effect of chronic heavy metals exposure on lipid metabolism.Chronic heavy metal exposure resulted in decrease in biochemical constituents of lipids, with decrease in hepatopancreatic weight, hepato -somatic index and embryonic length and weight.
\end{abstract}

Copyright (C) Raghavendra Rao M. V et al, 2017, this is an open-access article distributed under the terms of the Creative Commons Attribution License, which permits unrestricted use, distribution and reproduction in any medium, provided the original work is properly cited.

\section{INTRODUCTION}

Heavy metals are known to affect the reproduction and development of an organism and results in decrement of hepato-pancreatic weight, hepato-somatic index, and biochemical constituents of carbohydrate, proteins and lipids (1). Heavy metals are naturally occurring inorganic elements which are present in very small amounts in the living tissues but are important for the vital processes of life (2). Heavy metals have different sources. Mercury ( $\mathrm{Hg})$, Chromium $(\mathrm{Cr})$, Nickel (Ni) and Zinc (Zn) are the most naturally occurring heavy metals whereas lead $(\mathrm{Pb})$, Cadmium $(\mathrm{Cd})$, Copper $(\mathrm{Cu})$ and Arsenic (As) are the direct consequence of human environmental pollution. (3) Metals are involved in a range of physiological processes such as prosthetic groups of many proteins, water balance and cofactors of many enzymes (4).

The human health risk of heavy metals exposure is a public health problem. The exposure of heavy metals, in particular, $\mathrm{Pb}, \mathrm{Cd}, \mathrm{As}$, and methylmercury $(\mathrm{MeHg})$ directly interfere with brain development and results in cognitive impairment. The exact mechanism of their toxicity is still unknown but their synergistic effect is well defined (5). Uncontrolled pollution and industrialization might be a potential source to expose human population against toxic metals such as lead $(\mathrm{Pb})$, nickel (Ni), cadmium (Cd) and arsenic (As). Some of the toxic metals are implicated to disrupt the glucose uptake and alter the related molecular mechanism in glucose regulation $(6,7)$. Several studies have reported that the imbalance of essential metals have an adverse effect in the pancreatic islet and subsequently cause development of diabetes (8). Mercury ( $\mathrm{Hg})$ is known to be one of the most toxic heavy metals and it can markedly alter the metabolism and function of such essential trace elements as copper, zinc, iron, manganese, selenium and calcium by competing for ligands in biological systems (9). It is considered toxic to the kidneys, central nervous system, cardiovascular, gastrointestinal, and immune systems $(10,11)$. The effects of heavy metals in the metabolism of lipids can have profound effects in overall cellular function. Administration of heavy metals was shown to alter the lipid metabolism in various organisms. The present study showed a reduction in cholesterol within 15-days, possibly due to tissue damage in the kidney. On the contrary, inOreochromisniloticus, an increase in cholesterol was seen during a 21 day period due to cadmium. This alteration in cholesterol concentration could be due to hazardous effects of metals on cell membrane. Thus, increase in cholesterol levels are good indicators of environmental stress in fishes. (12). 
Exposure of Lymnaealuteola to copper sulphate induced marked decrease in lipid levels in the snail(13). Jayasree (14)studied the effects of copper sulphate and zinc sulphate on the biochemical composition of Bellamyadissimilis and found a marked decrease in total lipids concentration. Rats treated with sodium chromate and calcium chromate showed significant changes in the levels of total plasma protein and cholesterol (15). Oral administration of manganese chloride to rabbits significantly increased the serum cholesterol (16). On cadmium chloride administration to male albino rats, at an acute dose of $400 \mathrm{mg} /$ kilogram body weight/day for three days, the lipoperoxidative reactions in renal nuclear membrane were significantly increased (17). From the literature it is clear that administration of heavy metals alter the lipid metabolism. In viviparous, if such a situation occurs on exposure to heavy metals, the alteration in the lipid metabolism of the mother might influence the embryonic development. Therefore the objective of the study is to determine the effects of heavy metals on the lipid metabolism of H.fulvipes.

\section{MATERIAL AND METHODS}

An experimental prospective study was designed using the $H$. fulvipes. Three groups were formed based on heavy metal exposure: group I (control), group II(mercury exposure) and group III (lead exposure). Monthly samples were drawn from different groups after exposure to mercury and lead successively at the intervals of one month. Lipids were estimated in the maternal tissues (hepatopancreas, pedipalpal muscle and haemolymph) and the whole embryos in the samples drawn from group I, II and III. Samples drawn every month from August to April received one sublethal dose per month; hence the sample from the month of August represented the effect of a single dose, whereas samples taken at September represented cumulative effect of two doses. In the same order samples at the month of April represent the effect of nine sublethal doses of the heavy metals.

The tissues were homogenize in the chloroform methanol mixture $(2: 1 \mathrm{v} / \mathrm{v})$ and kept for 10 minutes. Mixtures obtained were filtered through a filter paper, prewashed with the solvent mixture into a glass stoppertest tube. The residues were extracted again with the same solvent mixture and the pooled supernatants were washed with $0.20 \mathrm{ml}$ of $0.90 \%$ sodium hydroxide by thorough mixing. The test tubes were kept in the refrigerator overnight. The mixture becomes biphasic containing lipids in the lower chloroform phase. The upper methanol phase containing the non - lipid contaminant is removed. The lower phase with the lipids was evaporated to dryness under vacuum. The dried residues were immediately treated with $3.0 \mathrm{ml}$ of $2.0 \%$ potassium dichromate in $96 \%$ Sulphuric acid and the reaction mixtures were kept in boiling water bath for 15 minutes. The contents were subsequently cooled under running tap water and $4.5 \mathrm{ml}$ of distilled water was added carefully along the sides of the test tube and mixed thoroughly. It was once again cooled under running water and the intensity of the color developed was read at $580 \mathrm{~m} \mu$ against a blank containing $3.0 \mathrm{ml}$ of $2 \%$ chromic acid. Lipid contents of the samples were calculated from a standard graph plotted using cholesterol.

\section{RESULTS}

\section{Effect of mercury and lead on the lipid content of hepatopancreas during gestation period}

The variation in the lipid content of hepatopancreas during the gestation period in control animalsexhibits an initial raise in September followed by a gradual decline till the end of gestation with a small peak during March (Table-1, Fig-30). Administration of monthly sublethal doses of mercury during the gestation period did not alter the variation; the pattern remained same as that of the controls. However, a significant reduction in the lipid content was registered except in the samples of August and October. The percentage depletion though was statistically significant, dose dependency was not conspicuous.

Administration of monthly doses of sub lethal concentration of lead also produced effects similar to those of mercury resulting in significantly lower levels of lipid throughout the gestation period.

Table 1 Effect of mercury $(\mathrm{Hg})$ and lead $(\mathrm{Pb})$ on the lipid content of the hepatopancreas of H.fulvipes during the gestation period.

Values represent mean \pm S.E. Number of observations $(\mathrm{N})=7$.

\begin{tabular}{|c|c|c|c|}
\hline \multirow{2}{*}{$\begin{array}{c}\text { Month of } \\
\text { Treatment }\end{array}$} & \multicolumn{3}{|c|}{ Lipid mg/100 mg wet wt. } \\
\hline & Control & Experimental & $\begin{array}{l}\text { PERCENT } \\
\text { Change }\end{array}$ \\
\hline \multirow[t]{2}{*}{ AUG } & $25.31 \pm 0.89$ & $\mathrm{Hg} 23.46 \pm 0.83^{*}$ & 7.32 \\
\hline & & $\mathrm{Pb} 22.31 \pm 1.49^{\mathrm{b}}$ & 11.89 \\
\hline \multirow{2}{*}{ SEP } & \multirow{2}{*}{$33.17 \pm 0.82$} & $\mathrm{Hg} \quad 30.70 \pm 0.60^{\mathrm{a}}$ & 7.45 \\
\hline & & $\mathrm{Pb} \quad 28.90 \pm 0.95^{\mathrm{b}}$ & 12.87 \\
\hline \multirow{2}{*}{ OCT } & \multirow{2}{*}{$28.52 \pm 0.95$} & $\mathrm{Hg} 26.56 \pm 0.98^{*}$ & 6.86 \\
\hline & & $\mathrm{Pb} 24.37 \pm 0.80^{\mathrm{b}}$ & 13.26 \\
\hline \multirow{2}{*}{ NOV } & \multirow{2}{*}{$25.26 \pm 0.63$} & $\mathrm{Hg} \quad 22.06 \pm 0.50^{\mathrm{c}}$ & 12.65 \\
\hline & & $\mathrm{Pb} \quad 21.03 \pm 0.49^{\mathrm{c}}$ & 16.74 \\
\hline \multirow{2}{*}{ DEC } & \multirow{2}{*}{$25.01 \pm 0.72$} & $\mathrm{Hg} \quad 22.69 \pm 0.81^{\mathrm{a}}$ & 9.27 \\
\hline & & $\mathrm{Pb} \quad 23.28 \pm 0.84^{*}$ & 6.9 \\
\hline \multirow{2}{*}{ JAN } & \multirow{2}{*}{$19.46 \pm 0.86$} & $\mathrm{Hg} \quad 16.40 \pm 0.49^{\mathrm{b}}$ & 15.72 \\
\hline & & $17.49 \pm 0.38^{\mathrm{a}}$ & 10.11 \\
\hline \multirow{2}{*}{ FEB } & \multirow{2}{*}{$21.52 \pm 0.62$} & $19.17 \pm 0.53 *$ & 10.91 \\
\hline & & $18.01 \pm 0.51^{\mathrm{c}}$ & 16.27 \\
\hline \multirow{2}{*}{ MAR } & \multirow{2}{*}{$23.23 \pm 0.69$} & $20.85 \pm 1.01 *$ & 10.24 \\
\hline & & $19.34 \pm 0.66^{\mathrm{c}}$ & 16.76 \\
\hline \multirow{2}{*}{ APR. } & \multirow{2}{*}{$18.19 \pm 0.46$} & $\mathrm{Hg} \quad 16.89 \pm 0.32^{\mathrm{a}}$ & 7.14 \\
\hline & & $15.62 \pm 0.65^{\mathrm{b}}$ & 14.13 \\
\hline
\end{tabular}

\section{Effect of mercury and lead on the lipid content of pedipalpal muscle}

The one to nine doses of the sublethal concentrations of mercury administered during the gestation period to gravid females did not bring about a significant effect on the lipid content of the pedipalpal muscle, as the depletion was statistically insignificant throughout the gestation period, except the December sample (Table-2, Fig-31).Sublethal doses of lead also brought about only a statistically insignificant depletion in the lipid content of the pedipalpal muscle except for the samples of August, September and December. 
Table-2 Effect of mercury $(\mathrm{Hg})$ and lead $(\mathrm{Pb})$ on the lipid content of the pedipapal muscle of H.fulvipes during the gestation period.

Values represent mean \pm S.E. Number of observations $(\mathrm{N})=7$.

\begin{tabular}{|c|c|c|c|}
\hline \multirow[b]{2}{*}{$\begin{array}{l}\text { Month of } \\
\text { Treatment }\end{array}$} & \multicolumn{3}{|c|}{ Lipid mg/100 mg wet wt. } \\
\hline & Control & Experimental & $\begin{array}{l}\text { Percent } \\
\text { change }\end{array}$ \\
\hline \multirow[t]{2}{*}{ AUG } & \multirow{2}{*}{$1.65 \pm 0.03$} & $\mathrm{Hg} 1.55 \pm 0.005^{*}$ & 6.45 \\
\hline & & $\mathrm{Pb} \quad 1.42 \pm 0.06^{\mathrm{b}}$ & 12.97 \\
\hline \multirow{2}{*}{ SEP } & \multirow{2}{*}{$1.62 \pm 0.03$} & $\mathrm{Hg} \quad 1.50 \pm 0.06^{*}$ & 7.69 \\
\hline & & $\mathrm{Pb} \quad 1.43 \pm 0.05^{\mathrm{b}}$ & 11.69 \\
\hline \multirow{2}{*}{ OCT } & \multirow{2}{*}{$1.33 \pm 0.05$} & $\mathrm{Hg} 1.23 \pm 0.07 *$ & 7.56 \\
\hline & & $\mathrm{Pb} \quad 1.21 \pm 0.07 *$ & 9.36 \\
\hline \multirow{2}{*}{$\mathrm{NOV}$} & \multirow{2}{*}{$1.27 \pm 0.05$} & $\mathrm{Hg} 1.21 \pm 0.08^{*}$ & 5.09 \\
\hline & & $\mathrm{Pb} 1.15 \pm 0.05^{*}$ & 9.55 \\
\hline \multirow{2}{*}{ DEC } & \multirow{2}{*}{$1.19 \pm 0.06$} & $\mathrm{Hg} \quad 1.13 \pm 0.04 \mathrm{a}^{*}$ & 9.70 \\
\hline & & $\mathrm{Pb} \quad 1.12 \pm 0.03^{\mathrm{b}}$ & 10.89 \\
\hline \multirow[b]{2}{*}{ JAN } & \multirow{2}{*}{$1.22 \pm 0.03$} & $\mathrm{Hg} \quad 1.10 \pm 0.03 *$ & 8.18 \\
\hline & & $1.15 \pm 0.03 *$ & 3.42 \\
\hline \multirow{2}{*}{ FEB } & \multirow{2}{*}{$1.24 \pm 0.06$} & $1.12 \pm 0.04 *$ & 7.61 \\
\hline & & $1.18 \pm 0.02 *$ & 3.91 \\
\hline \multirow{2}{*}{ MAR } & \multirow{2}{*}{$1.24 \pm 0.06$} & $1.22 \pm 0.08 *$ & 1.92 \\
\hline & & $1.20 \pm 0.07 *$ & 3.05 \\
\hline \multirow{2}{*}{ APR. } & \multirow{2}{*}{$1.08 \pm 0.04$} & $1.02 \pm 0.05^{*}$ & 5.99 \\
\hline & & $\mathrm{Pb} \quad 0.97 \pm 0.05^{*}$ & 9.95 \\
\hline
\end{tabular}

Effect of mercury and lead on the lipid content of the haemolymph during gestation period

The lipid content in haemolymph showed a mean gradual decline during the gestation period from September to April both in the controls and the experimental animals treated with mercury and lead. Though the pattern of variation of lipid in the haemolymph was same both in the controls and experimental animals, animals treated with heavy registered a highly significant depletion (Table-3, Fig-32). The sublethal dose of lead (1/3 LD50 value) depresses lipids much more than

Table 3 Effect of mercury $(\mathrm{Hg})$ and lead $(\mathrm{Pb})$ on the lipid content of the hemolymph of $H$. fulvipes during the gestation period

Values represent mean \pm S.E. Number of observations $(\mathrm{N})=8$.

\begin{tabular}{ccccc}
\hline $\begin{array}{c}\text { Month of } \\
\text { Treatment }\end{array}$ & Control & Experimental & $\begin{array}{c}\text { Percent } \\
\text { change }\end{array}$ \\
\hline \multirow{2}{*}{ AUG } & $339.37 \pm 8.81$ & $\mathrm{Hg} 366.87 \pm 7.55^{\mathrm{b}}$ & 6.45 \\
& & $\mathrm{~Pb} 350.62 \pm 7.47^{\mathrm{c}}$ & 12.97 \\
$\mathrm{SEP}$ & $431.25 \pm 11.92$ & $\mathrm{Hg}$ & $387.50 \pm 7.07^{\mathrm{b}}$ & 7.69 \\
& & $\mathrm{~Pb}$ & $364.37 \pm 8.02^{\mathrm{c}}$ & 11.69 \\
$\mathrm{OCT}$ & $421.00 \pm 12.52$ & $\mathrm{Hg} 373.12 \pm 7.59^{\mathrm{b}}$ & 7.56 \\
& & $\mathrm{~Pb} 358.75 \pm 8.13^{\mathrm{c}}$ & 9.36 \\
$\mathrm{NOV}$ & $414.00 \pm 11.75$ & $\mathrm{Hg}$ & $359.37 \pm 7.67^{\mathrm{c}}$ & 13.19 \\
& & $\mathrm{~Pb} 344.37 \pm 8.36^{\mathrm{c}}$ & 9.55 \\
$\mathrm{DEC}$ & $418.37 \pm 10.71$ & $\mathrm{Hg}$ & $370.12 \pm 8.65^{\mathrm{b}}$ & 13.20 \\
& & $\mathrm{~Pb}$ & $348.12 \pm 6.81^{\mathrm{c}}$ & 16.79 \\
$\mathrm{JAN}$ & $398.37 \pm 8.12$ & $\mathrm{Hg}$ & $355.00 \pm 10.53^{\mathrm{b}}$ & 10.88 \\
& & $\mathrm{~Pb}$ & $345.00 \pm 10.82^{\mathrm{c}}$ & 13.39 \\
FEB & $385.62 \pm 10.43$ & $\mathrm{Hg}$ & $352.50 \pm 10.26^{\mathrm{a}}$ & 8.58 \\
& & $\mathrm{~Pb}$ & $335.62 \pm 8.50^{\mathrm{c}}$ & 12.96 \\
$\mathrm{MAR}$ & $403.37 \pm 7.63$ & $\mathrm{Hg}$ & $368.12 \pm 9.63 \mathrm{~b}^{*}$ & 8.27 \\
& & $\mathrm{~Pb}$ & $355.15 \pm 8.71^{\mathrm{c}}$ & 11.98 \\
$\mathrm{APR}$. & $366.25 \pm 8.11$ & $\mathrm{Hg}$ & $315.62 \pm 5.18^{\mathrm{c}}$ & 13.82 \\
& & $\mathrm{~Pb}$ & $303.00 \pm 4.24^{\mathrm{c}}$ & 17.27 \\
\hline $\mathrm{a}_{\mathrm{p}}<0.05 ;$ & $\mathrm{b}_{\mathrm{p}}<0.01 ;$ & & $\mathrm{c}_{\mathrm{p}}<0.001$ &
\end{tabular}

thesublethal dose of mercury (1/10 LD50 value) administered to the gravid females during the gestation period.

\section{Effect of mercury and lead on the lipid content of the embryo during gestation period}

The lipid content of the embryos in the control animals exhibited a gradual increase right from the beginning of gestation period till the end following a sigmoid growth pattern. Treatment of the maternal animals with sub lethal doses of either mercury or lead did not exert any significant effect on the lipid content of the embryos. The pattern of variation throughout the gestation period was similar to that of controls and the depletion in the lipid content was not statistically significant, except in the lead treatment samples of November, January, March and April (Table-4, Fig-33).

Table4 Effect of mercury $(\mathrm{Hg})$ and lead $(\mathrm{Pb})$ on the lipid content of the embryos of $H$. fulvipes during the gestation period.

Values represent mean \pm S.E. Number of observations $(\mathrm{N})=8$.

\begin{tabular}{|c|c|c|c|}
\hline \multirow{2}{*}{$\begin{array}{l}\text { Month of } \\
\text { Treatment }\end{array}$} & \multicolumn{3}{|c|}{ Lipid mg/embryo } \\
\hline & Control & Experimental & Percent change \\
\hline \multirow{2}{*}{ SEP. } & \multirow{2}{*}{$0.05 \pm 0.004$} & $\mathrm{Hg} \quad 0.05 \pm 0.004^{*}$ & 10.16 \\
\hline & & $\mathrm{Pb} \quad 0.05 \pm 0.004 *$ & 13.56 \\
\hline \multirow{2}{*}{ OCT. } & \multirow{2}{*}{$0.11 \pm 0.007$} & $\mathrm{Hg} 0.11 \pm 0.004^{*}$ & 13.56 \\
\hline & & $\mathrm{Pb} 0.10 \pm 0.006^{*}$ & 5.17 \\
\hline \multirow{2}{*}{ NOV. } & \multirow{2}{*}{$0.13 \pm 0.009$} & $\mathrm{Hg} 0.12 \pm 0.008^{*}$ & 7.14 \\
\hline & & $\mathrm{Pb} 0.11 \pm 0.006^{\mathrm{a}}$ & 13.33 \\
\hline \multirow{2}{*}{ DEC. } & \multirow{2}{*}{$0.27 \pm 0.01$} & $\mathrm{Hg} \quad 0.24 \pm 0.01 *$ & 13.97 \\
\hline & & $\mathrm{Pb} \quad 0.23 \pm 0.01 *$ & 15.41 \\
\hline \multirow{2}{*}{ JAN. } & \multirow{2}{*}{$0.92 \pm 0.02$} & $\mathrm{Hg} \quad 0.88 \pm 0.01 *$ & 4.63 \\
\hline & & $\mathrm{Pb} \quad 0.86 \pm 0.01^{\mathrm{a}}$ & 6.89 \\
\hline \multirow{2}{*}{ FEB. } & \multirow{2}{*}{$2.64 \pm 0.03$} & $\mathrm{Hg} \quad 2.31 \pm 0.04^{\mathrm{a}}$ & 6.89 \\
\hline & & $\mathrm{Pb} \quad 2.09 \pm 0.03^{\mathrm{a}}$ & 12.29 \\
\hline \multirow{2}{*}{ MAR. } & \multirow{2}{*}{$2.85 \pm 0.10$} & $\mathrm{Hg} \quad 2.58 \pm 0.09^{*}$ & 9.45 \\
\hline & & $\mathrm{Pb} \quad 2.45 \pm 0.08^{\mathrm{b}}$ & 14.24 \\
\hline \multirow{2}{*}{ APR. } & \multirow{2}{*}{$3.26 \pm 0.09$} & $\mathrm{Hg} \quad 2.95 \pm 0.12^{*}$ & 10.09 \\
\hline & & $\mathrm{Pb} \quad 2.84 \pm 0.13^{\mathrm{a}}$ & 12.79 \\
\hline
\end{tabular}

$\mathrm{a}_{\mathrm{p}}<0.05: \mathrm{b}_{\mathrm{p}}<0.01 \quad *$ - insignificant

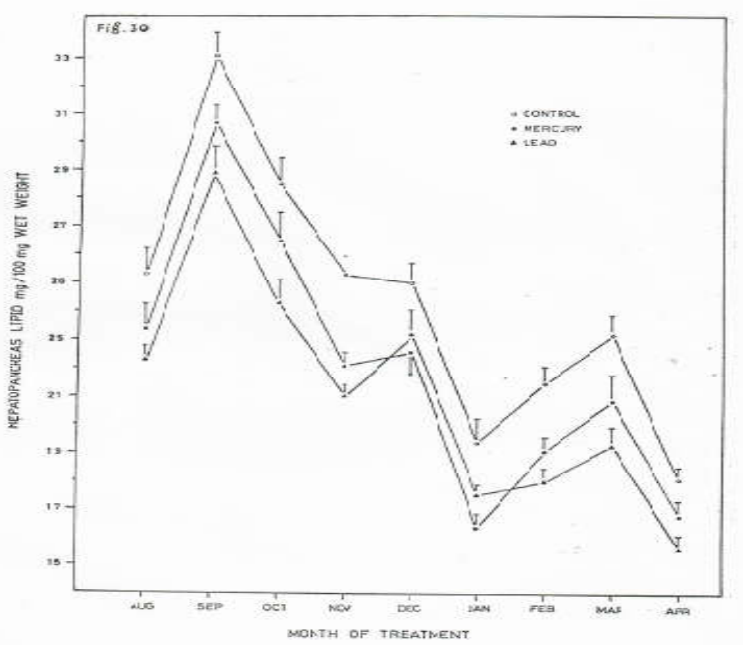

Fig 30 Effect of mercury $(\mathrm{Hg})$ and lead $(\mathrm{Pb})$ on the lipid content of the hepatopancreas of $H$. fulvipes during the gestation period. 


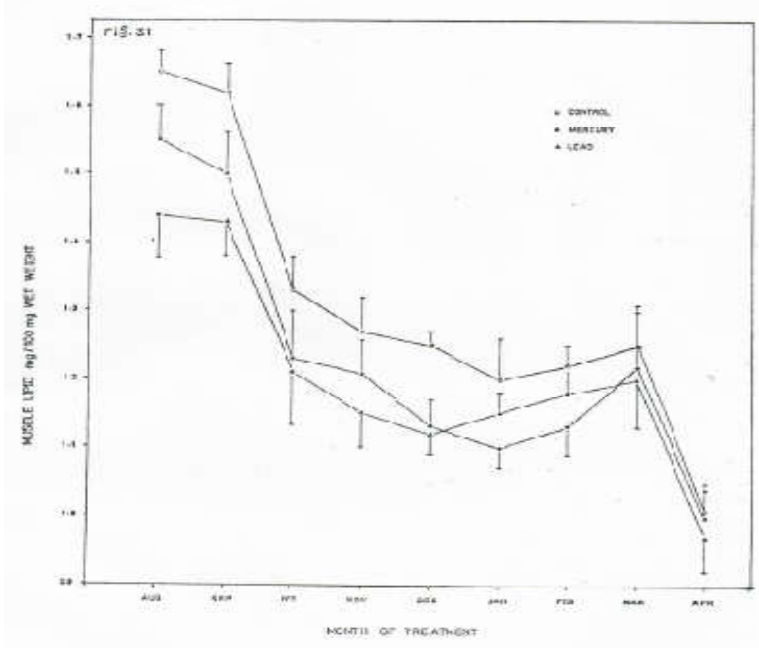

Fig 31Effect of mercury $(\mathrm{Hg})$ and lead $(\mathrm{Pb})$ on the lipid content of the pedipapal muscle of $H$. fulvipes during the gestation period.

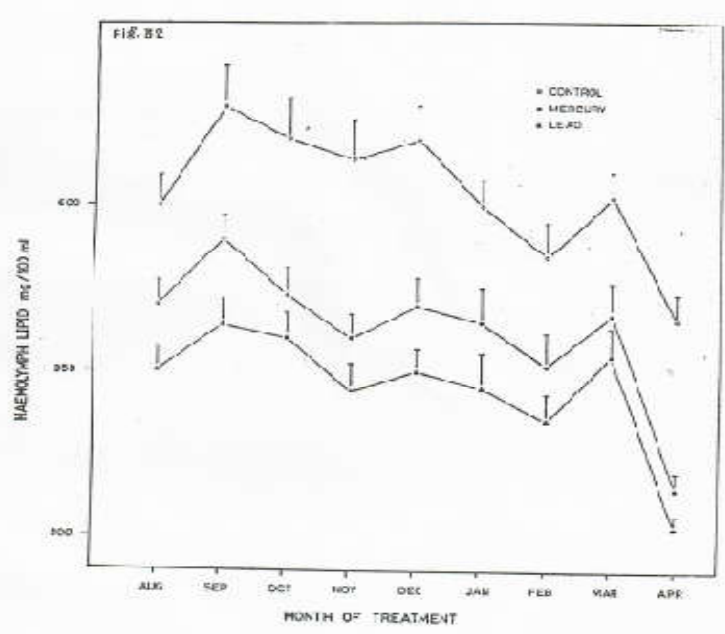

Fig 32 Effect of mercury $(\mathrm{Hg})$ and lead $(\mathrm{Pb})$ on the lipid content of the hemolymph of $H$. fulvipes during the gestation period.

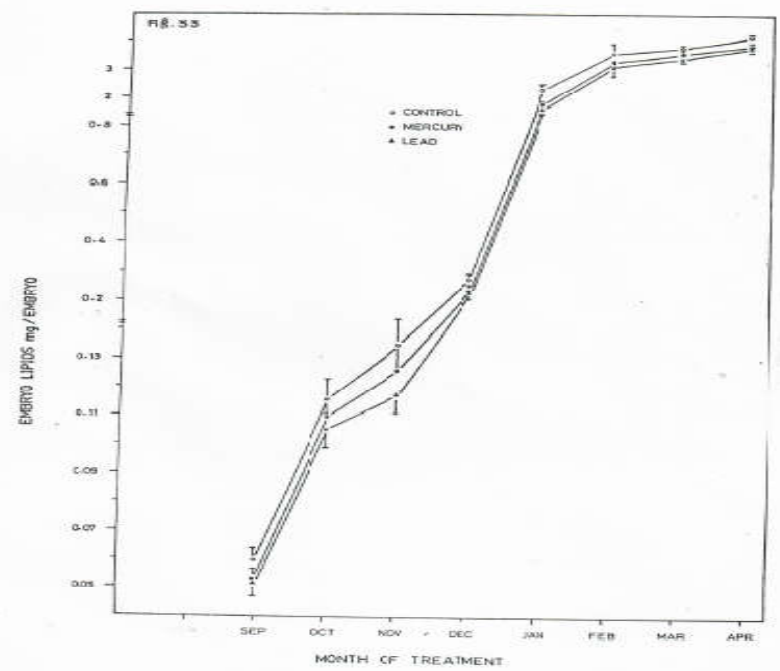

Fig 33 Effect of mercury $(\mathrm{Hg})$ and lead $(\mathrm{Pb})$ on the lipid content of the embryos of $H$. fulvipes during the gestation period.

\section{DISCUSSION}

There have been multiple proven reports of the depletion of the lipids following the treatment of different species of animals with heavy metals $(13,14)$. Triglyceride functions primarily in providing cellular energy and can be used as an indicator of nutritional status. The results obtained for the effects of mercury and lead on the lipid contents of the maternal hepatopancreas, haemolymph and pedipalpal muscle of $H$. fulvipes during gestation period are also in conformity with the above findings. Lipids being the high energy yielding food stuffs, the depletion of the lipids in the maternal tissues of $H$. fulvipes is perhaps a consequence of the utilization of lipids on the phase of increased demands of energy under the heavy metal stress. The possibility of utilization of lipids for gluconeogenesis is ruled out as the glycogen content of maternal tissues is also depleted under the stress of lead and mercury in the present study. Hence the suggestion that lipids are used for yielding energy under the heavy metal stress gains strength.

Lipids are known to play a significant role not only as energy source for embryogenesis but also by providing structural components during embryogenesis and growth. Hence any reduction in the lipids available to the developing embryos from the viviparous mother during gestation would proportionately affect the development. It has been shown in chapter that the size and weight of the embryos of $H$. fulvipes were significantly reduced following repeated administration of sublethal doses of mercury and lead during gestation period to the maternal animal. It was also shown that parturition failed in H.fulvipes in cases where the maternal animal received nine monthly doses of mercury and eight of lead. It could be suggested that depletion of maternal lipid stores available for the embryogenesis, under the stress of heavy metals possibly is responsible is responsible for the observed effects of the two heavy metals on the embryos and parturition of H.fulvipes.

\section{CONCLUSION}

The results obtained in the present study showed that though there is a reduction in the rate of accumulation of lipids in the embryos when the maternal animals were exposed to lead and mercury, the reduction was not statistically significant. Hence it proves hard to hold the lipids wholly responsible for the observed effects of the mercury and lead in the development of H. fulvipes. It was noticed earlier that both mercury and lead lowered the protein content and glycogen stores of the maternal tissues and embryos. It is therefore suggested that a general nutrient deficiency, owing to excessive utilization by the maternal animal under heavy metal stress, is responsible both for embryonic size reduction and failures of parturition.However, the direct effect of lead and mercury on the embryonic development cannot also be completely ruled out.

\section{References}

1. M.V.Raghavendra Rao,Yogesh Acharya, SireeshaBala,Simi Paramban. The study of heavy metals in abnormal growth and development using an alternate animal model Heterometrousfulvipes. Int. J. life sciences Res. 2017;3;800-807.

2. Kazi TG, Afridi HI, Kazi N, Jamali MK, Arain MB, Jalbani N, Kandhro GA. Copper, chromium, manganese, iron, nickel, and zinc levels in biological samples of diabetes mellitus patients. Biol Trace Elem 
Res. 2008;122(1):1-18. doi: 10.1007/s12011-007-8062y. (PubMed) (Cross Ref) (Ref list)

3. Chen M,Lu W,Hou Z, Zhang Y,Jiang X, Wu J.Heavy metal pollution in soil associated with a large scale cyanidation gold mining region in south east of Jilin, China, Environ Sc pollute Res int.2016 17, DOI;10.1007/s11356-016-7968-3.

4. Fraga CG. Relevance, essentiality and toxicity of trace elements in human health. Mol Aspects Med. 2005;26(45):235-244. (PubMed) (Ref list)

5. Karri V, Kumar VM. Heavy metals ( $\mathrm{Pb} \mathrm{Cd}$, As, and Me $\mathrm{Hg}$ ) are risk factors for cognitive dysfunction. A general review of metal mixture mechanism in brain. Environ. ToxicolPharmacol. 2016; 26,48;203-213. Doi:10.1016/j.etap2016.09.016

6. Kazi TG, Jalbani N, Kazi N, Arain MB, Jamali MK, Afridi HI, Kandhro GA, Sarfraz RA, Shah AQ, Ansari R. Estimation of toxic metals in scalp hair samples of chronic kidney patients. Biol Trace Elem Res. 2009;127(1):16-27.doi:10.1007/s12011-008-82228.(PubMed)

7. Serdar MA, Bakir F, Hasimi A, Celik T, Akin O, Kenar L, Aykut O, Yildirimkaya M. Trace and toxic element patterns in nonsmoker patients with noninsulindependent diabetes mellitus, impaired glucose tolerance, and fasting glucose. Int $J$ Diabetes Dev Ctries. 2009;29(1):35-40. doi: 10.4103/09733930.50713.(PMC free article)(PubMed)(Cross Ref) (Ref list

8. Chen YW. Heavy metals, islet function and diabetes development. Islets. 2009;1(3):169-

176.doi:10.4161/isl.1.3.9262. (PubMed)(Cross Ref).

9. Taylor DM, Williams DR. Trace element medicine and chelation therapy. The Royal Society of Chemistry, 1995.
10. Holmes P, James KA, Levy LS. Is low-level environmental mercury exposure of concern to human health? Sci Total Environ. 2009; 8: 171-182.

11. Virtanen JK, Rissanen TH, Voutilainen S, Tuomainen TP. Mercury as a risk factor for cardiovascular diseases. J NutrBiochem.2007; 18: 75-85.

12. Oner M, Atli G, Canli M. Changes in serum parameters of freshwater fish Oreochromisniloticus following prolonged metal (Ag, $\mathrm{Cd}, \mathrm{Cr}, \mathrm{Cu}, \mathrm{Zn})$ exposures. Environ Toxicol Chem. 2008;2:360366. (PubMed)(Oncorhynchus mykiss)

13. Reddy B. Alterations in organic content and caloric value of the snail vector Lymnaealuteola during different chemical exposures.Giobios. 1983; 10(4);191-192.

14. Jayasree N. Some aspects of the toxicity of copper and zinc to the fresh water snail Bellamyadissimilis (Muller), M.Phill, thesis Nagarjuna University (India), 1984.

15. Steinhoff D, Gad SC, Hatfield GK, Mohr U. testing sodium dichromate and soluble calcium chromate for carcinogenicity in rats. Report to the industrial health foundation, Wuppertal, Bayer AG Inst. of Toxicology.1983; 126pp.

16. Khandelwal S, Tandon SK. Effect of manganese on certain enzymes and constituents of blood and serum in rabbits. II Environ. Res. 1981; 24: 82-88.

17. Das MN, Ghosh D, Chatopathyay SA, Chatterjee GC. Effects of acute oral administration of cadmium chloride on uptake of element and control of lipoperoxidative process in hepatic and renal nuclear fractions of rats. Ind. J. Expt. Biol. 1988; 26: 449-452.

\section{How to cite this article:}

Raghavendra Rao M. V et al.2017, Mercury and Lead Toxicity Induced Alterations In The Lipid Metabolism of Heterometrousfulvipes: A Study Through Direct Exposure. Int J Recent Sci Res. 8(5), pp.17260-17264.

DOI: http://dx.doi.org/10.24327/ijrsr.2017.0805.0317 